\title{
MOVING FROM PILGRIMAGE TO "DARK" TOURISM: LEVERAGING TOURISM IN PALESTINE
}

\author{
RAMI K. ISAAC* and GREGORY J. ASHWORTH† \\ *Center for Cross-cultural Understanding, NHTV Breda University of Applied Sciences, The Netherlands \\ $\uparrow$ Heritage Management and Urban Tourism, Faculty of Spatial Sciences, \\ University of Groningen, The Netherlands
}

\begin{abstract}
Traveling to places associated with death is not a new phenomenon. People have long been drawn, purposefully or otherwise, towards sites, attractions, and events linked in one way or another with death, suffering, violence, or disaster. War-related attractions, though diverse, are a subset of the totality of tourist sites associated with death and suffering. This article aims to assess how "dark" tourism may play a role in leveraging tourism in Palestine, which has largely relied on pilgrimage tourism in the past. This article investigates the potential for developing this form of tourism, since Palestine has been undergoing death, suffering, violence, or disaster through political tension and instability since 1948 and arguably for a generation earlier, but has not yet developed a strategy for tourism development that considers this type of tourism.
\end{abstract}

Key words: Palestine; Suffering; Wall; Dark tourism; Pilgrimage

Introduction

Traveling to places associated with death is not a new phenomenon. People have long been drawn, purposefully or otherwise, towards sites, attractions and events linked in one way or another with death, suffering, violence, or disaster. Examples of these types of tourist attractions include the sixth floor in the Book Depository, Dallas, Texas (Foley \& Lennon, 1996a), graveyards (Seaton, 2002), sites of the Jewish holocaust (Ashworth, 1996; Beech,
2000), atrocities (Ashworth \& Hartmann, 2005), and prisons - past and present (Dann \& Seaton, 2001; Strange \& Kempa, 2003; Wilson, 2004).

This type of tourism is also a phenomenon that has become both widespread and diverse. Smith (1998) suggests that sites or destinations associated with war, for example, probably constitute "the largest single category of tourist attractions in the world" (p. 205). Some have argued that war-related attractions, though diverse, are a subset of the totality of tourist sites associated with death and 
suffering (Dann, 1998; Stone, 2006). Examples of dark tourism are today visible and clear in Iraq, Afghanistan, Palestine, and Israel (Kroitoru, 2008), although not all visits to sites related to war are visited with "dark" motives. Some dark tourism is motivated by historical interest and family links. It is tourism of a seemingly "dark" variety one that stands distinctly apart from its sea-sun-and-sand counterpart that has travelers heading to the Middle East not only despite war and conflict but also at times because of it. Witnessing the damage caused by an Israeli rocket in one of the hotels in Bethlehem, visiting the site of poison gas attacks in northern Iraq, and touring the bullet-ridden buildings of Beirut are just a sampling of the Middle East's debatably "dark" tourist attractions, places associated in some way with death, destruction, conflict, and war.

Pakistani, British, and other tour operators specializing in adventure tourism are increasingly including Afghanistan among their destinations. Recently, a single tour operator based in Kabul has also emerged. These tourists are limited to a few thousand each year, but in the short term this appears to be the most likely source of inbound travel for Afghanistan (Euromonitor, as cited in Tourism-Review.com, 2009). In the Bamiyan Valley, north of the Afghanistan capital Kabul, for example, a new Tourism Information Center has been developed and the local authority is investing money to train tour guides in an effort to boost dark tourism in this part of the country.

The spatial context of this article is Palestine. The Holy Land has always been an important destination for Christian, Jewish, and Muslim pilgrims from all over the world. Go on pilgrimage to The Holy Land; the nomenclature and definite article are notable, and its sites, especially Jerusalem, Bethlehem, and Nazareth, were visited as early as the 2nd century AD (Kolby, 1983). Pilgrimage and hospitality have been defining features of the economy and society of the Holy Land and Palestine for 2000 years (Collins-Kreiner, Kliot, Mansfeld, \& Sagi, 2005; Isaac, 2008). However, the PalestinianIsraeli conflict has introduced Palestine to a reality of fluctuating political violence and counterviolence, tensions, and instability.

Relatively little attention has been paid in the academic literature on tourism development, to the difficulties, impediments, potential, and growth in Palestine. Tourism in the Middle East has been addressed generally (see, e.g., Daher, 2006; Kliot \& Collins-Kreiner, 2003; Mansfeld, 1999; Wahab, 2000) but work on Palestine has been the exception (see, e.g., Al-Rimmawi, 2003; Clarke, 2000; Isaac, 2008, 2009, 2010a).

The overall aim of this article is to assess how dark tourism may play a role in providing a different form of tourism as an "add on" to pilgrimage tourism, which is the existing dominant type of tourism to Palestine. This article investigates the potential for developing this form of tourism, since Palestine has experienced death, suffering, violence, or disaster through political tension and instability since 1948, and arguably for a generation earlier. Yet, dark tourism but has not yet been developed in Palestine.

The trouble really began (although Zionism predates the First World War and Balfour declaration) during the British mandate and intensified after the 1948 "Al-Nakba" meaning the "disaster," "catastrophe," or "cataclysm” (Cleavland, 2004).

\section{Dark Tourism}

Foley and Lennon (1996a, 1996b) have long argued that there has been a significant growth in tourism associated with sites of death and disaster. They also coined the term "dark tourism," which subsequently became the title of a book that remains the most widely cited study of this phenomenon. Although their work was not primarily focused upon the link between tourism and death, others have attempted to refine and illustrate the idea (Ashworth, 1996; Seaton, 2002).

Uzell (1989) argued for the "hot" interpretation of battle and conflict (interpretation that is an intense or passionate reaction to the site/event), whereas Tunbridge and Ashworth (1996) following work on "dissonant heritage" extended an essential conceptual framework for the management of such sites. More recently, Wight and Lennon (2007) examined selected interpretations at dark heritage sites in Lithuania, proposing that "moral complexities" guarantee that important eras of history remain absent and uninterpreted in the nations' collective memorialization and celebration of its past. Similar studies by Muzanini, Teo, and Yeoh, (2007) 
examine the interpretation of Singapore's Fort Silso, which emerged as a product to cater to contemporary demands of visitors wishing to encounter sites of death and atrocity (Lennon \& Foley, 2000; Seaton, 1999).

A number of commentators have claimed that dark tourism attractions challenge the inherent order, rationality, and progress of modernity (Stone \& Sharpley, 2008). Uriely (2005) argues that there are discernible new trends within tourism that can be regarded as indications of postmodernity. Tourists are now more knowledgeable, critical, highly selective, highly segmented, and more discerning than they were, which has led to two consequences for tourism sites. First, the experiential and the visual are favored, and secondly, there is an avoidance of historical interpretations in order to render such sites more universally appealing.

In the process, local specificities become "watered down" and the site begins to resemble other similar sites, thus corresponding to Harvey's (1995) argument about the paradox of postmodernity "where places that seek to differentiate themselves [still] end up creating a kind of serial replication of homogeneity" (p. 8). Others (e.g., Poria \& Ashworth, 2009) have considered that dark tourism is not a challenge to modernity but confirmation of it.

During the 1990s other terms (thanatourism, black spot tourism, and atrocity heritage) were coined to make sense of the packaging and consumption of death as a tourist experience (Rojek, 1993; Seaton, 1996; Tunbridge \& Ashworth, 1996). Blom (2000) also defines a "morbid tourism" as a tourism that "focuses on sudden death and which quickly attracts large numbers of people" (p. 32). Consequently, Stone and Sharpley (2008) note that dark tourism turned to be many-sided by several variables, which some of these include the immediacy and spontaneity of "sensation" tourism to sites associated with death and disaster compared with premeditated and organized visits. There is also a distinction between sites and experiences that are purposefully constructed and that occur accidentally or incidentally (i.e., graveyards or roadsides memorials). Stone and Sharpley (2008) also point out that an interest in death may not be the only or most important reason for both the production and consumption of such sites.
For Foley and Lennon (1996a), the term "dark tourism" relates primarily to "the presentation and consumption by visitors of real and comodified death and disaster sites." Stone and Sharpley (2008, p. 574) commented on this definition by Foley and Lennon, reflecting Rojek's (1993) position, that it is largely dependent on the ability of global communication technology to instantly report items and subsequently repeat them ad infinitum. Consequently, they conclude that attractions based on events that neither took place "within the memories of those still alive to validate them" (Lennon \& Foley, 2000, p. 12) nor induce a sense of anxiety about modernity do not qualify to be dark tourism attractions. This seems, however, to betray a very naive view of fallible human memory as the sole means of validation.

In contrast, Seaton (1996) notes that dark tourism has a long history stemming from what he claims to be a "thanatopic tradition" that dates back to the Middle Ages, which intensified throughout the late 18 th and early 19 th century with visits to, for example, the battlefield of Waterloo (Seaton, 1999). He suggested that thanatourism was just the "travel dimension of thanatopsis," defined as "travel to a location wholly, or partially, motivated by the desire for actual or symbolic encounters with death, particularly, but not exclusively, violent death" (Seaton, 1996, p. 240).

As a diverse and fragmented set of dark tourism suppliers exist, so equally diverse are the motives of tourists who visit and consume these products. The difficulty of attaching an all encompassing label to the enormous diversity of dark sites, attractions, and experiences, has been recognized by many scholars, who have attempted to classify different forms or intensities of dark tourism (see Miles, 2002; Ryan \& Kohli, 2006; Sharpley, 2005). However, the fundamental motivational issue remains largely unresolved. In other words, despite the variety of approaches to dark tourism in the literature, the question of why tourists seek for such dark sites has attracted some attention. It is necessary, therefore, to have some understanding of tourist behavior with regards to dark tourism. Obviously, no analysis of dark tourism supply can be complete if tourist behavior and demand for the dark tourism product are not recognized. A variety of motives for dark tourism have been proposed in 
the tourism literature (see Rojek, 1997; Seaton, 1999; Tarlow, 2005; Wight \& Lennon, 2002) and most extensively by Dann (1998), who suggests eight influences for dark tourism, including the fear of phantoms; the search for novelty; nostalgia; the celebration of crime or deviance; basic bloodlust; and, at a more practical level, "dicing with death," undertaking journeys or "holiday in hell" that confront tourists or heighten their sense of humanity. However, Dann also recognizes that these classifications are largely descriptive and may be related to specific attractions, destinations, or activities rather than to individuals' motivations. Nonetheless, much of the literature remains focused upon supply while the motivations for dark tourism have yet to be thoroughly investigated.

\section{War, Political Instability, and Tourism}

The perception of safety and security is a major determinant in the travelers' decision to visit a destination (Beirman, 2003). Mitchell and Vasso (1997) and Irvine and Anderson (2006) found that risk perception, rather than facts or actual risk circumstances, influences tourists' behavior to avoid or cancel travel to a destination. Roehl and Fesenmaier (1992) argue, in general, that tourists make their travel decisions based on perceptions rather than reality.

Any conflict where people are dying means definitely a negative impact on the local tourism businesses, although it depends on who is dying. The perception of a personal threat to the visitor is crucial. Tourists freely visit poor countries where people may be routinely dying of hunger and disease as long as they do not perceive it as a threat. However, not many tourists wish to travel to countries at war. No matter that most of Israel/Palestine was a safe destination during the Gaza invasion in December 2008 by Israel-travelers naturally thought twice before deciding to visit the region. However, it depends if the tourist thinks there is a risk to themselves. Other people dying are probably not a problem. Take the example of tourism to Florida, which seems unaffected by a particularly high rate of violent crime in the local community (Milman \& Bach, 1999; Schiebler, Crofts, \& Hollinger, 1996).

The Gaza invasion by Israel along with the global economic crisis will probably have a negative effect on tourism in Israel as well as in Palestine. Also, the travel trade in Jordan and Egypt is likely to suffer from the clash, although it is not directly participating. This raises an interesting point about how tourists assess risk areas. Greater familiarity, and probably proximity, the more localized the risk area and the more distant or unfamiliar, the wider the definition of the risk area. It is clear that political instability influences the flows of tourism to the countries that are directly involved in the conflict. Nevertheless, political instability and its resultant negative image have no deference for international boundaries. Even when conflicts are entirely restricted within one or two countries, like Palestine and Israel, the effects are much more far-reaching. Mansfeld (1996) suggests that the Arab-Israeli wars obviously have caused a decline in tourism in Israel and Palestine, and other Arab neighbors. On a global level, for example, the Gulf War of 1991 was blamed for a slow growth of international arrivals in places as far away as Southeast Asia and Australia. On a smaller scale, conflicts and political instability in one country often negatively influence tourism in contiguous countries. Richter (1992) pointed out that political instability in one country may affect tourism in another country, even when the conflict does not actually spill across the border. Disturbances in one region (such as Palestine and Israel) can make the entire region appear unstable (Middle East). For example, Croatia continued to feel the negative effects of the ongoing war in neighboring Bosnia-Herzegovina long after its war had ended. According to PanicKombol (1996, p. 21), the war in Bosnia has generated deep negative connotations among potential tourists that Croatia is a dangerous tourist destination. Mansfeld (1996) asserts that this is in large part a result of the role of the media in covering these events. Much of what journalists report is exaggerated and fails to differentiate international problems from national ones as well perhaps as the potential tourist's poor knowledge of geography.

According to Urry (1990, p. 1), at least part of the tourist experience consists of gazing upon "a set of different scenes, of landscapes or townscapes, which are out of the ordinary. When tourists 'go away,' they look at the environment with interest and curiosity" (p. 1) The interest is motivated by the difference between what the tourist sees and 
experiences while away and what the tourist used to see and experience in their every day routine life back home. Urry (1990) expressed this as "a limited breaking with established routines and practices of everyday life ... allowing one's senses to engage with a set of stimuli that contrast with the everyday and the mundane" (p. 1). However, this is only half the story. Tourists may seek the familiar and the unfamiliar. The important question is: How can these two be reconciled? Is it a search for the unfamiliar within the security of the familiar and the acceptable dimensions of each condition. In any case, research has shown that violence and political instability may have severe impacts on tourism (Hall, 1994; Sönmez, 1998). Roehl's (1995) examination of the aftermath of the 1989 Tiananmen Square incident found that the event severely reduced foreign tourist arrivals in China for a couple of years because it interrupted growth from a number of key markets, such as Japan, the US, and Western Europe. Several border regions have always been plagued with disagreements, disputes, and political sensitivity-troubles that can indeed function as major hurdles to tourism. Tourism, in common with many other service industries, is responsive (Timothy, 2001). Tourists want to feel safe while traveling abroad, and if their security is under consideration, fewer people will travel, or they choose alternative, safer destinations. This is again a half-truth as people want to feel both safe and unsafe. This is the fair-ground or dangerous sport situation, where the thrill comes from a danger that is constrained.

Hall and O'Sullivan (1996) explained that

political instability described as a situation in which conditions and mechanisms of governance and rule are challenged as to their political legitimacy by elements operating from outside of the normal operations of the political system. When challenge occurs from within a political system and the system is able to adopt and change to meet demands on it, it can be said to be stable. When forces for change are unable to be satisfied from within a political system and then use such nonlegitimate activities as protest, violence, or even civil war to seek change, then a political system can be described as being unstable. (p. 106)

Obviously, there are degrees of political instability.

In addition, political instability describes the condition of a country where a government "has been toppled, or is controlled by factions following a coup, or where basic functional prerequisites for social-order control and maintenance are unstable and periodically disrupted" (Cook, 1990, p. 14). Richter and Waugh (1986) assert that "tourism may turn down sharply when political conditions become unsettled. Fewer tourists will travel and/or choose safer destinations" (p. 231). Present examples of highly publicized political conflicts include the 1991 disintegration of Yugoslavia and the ensuing war in Bosnia-Herzegovina; racial, ethnic, religious conflicts in Burundi, India, Pakistan, Rwanda, Somalia, and South Africa; student unrest in China and North Korea; and the ongoing PalestinianIsraeli conflict in the Middle East.

Political instability and violence are not necessary related. There has been enormous political instability in Belgium and Italy or in France 19481959 , in the sense of no stable government. There was, however, little or no violence. Equally, violence can exist within very stable governments, such as Apartheid South Africa. Political conflict and unrest may have a huge impact and threatening both the safety of specific countries and entire regions in the Middle East (Hall \& O'Sullivan, 1996; Sönmez, 1998; Wieviorka, 1994). Nevertheless, the real subject here is personal safety.

Political stability or instability influences tourists' real and perceived safety, and their image of a destination (Hall \& O’Sullivan, 1996). Evidence from around the world reveals and demonstrates that conditions of safety and security are necessary for tourism to flourish (Pizam, Tarlow, \& Bloom, 1997; Sönmez, 1998), and security anxiety, either from war, conflict, or civil unrest, may have highly destructive impacts on volatile tourism.

Without a doubt, the impact of political instability, violence, bloodshed, and war on tourism is a well-investigated area (Gartner \& Shen, 1992; Hall, 1994; Mansfeld \& Kliot, 1996; Mihalic, 1996; Pitts, 1996; Richter, 1980; Schwartz, 1991; Scott, 1988; Sharpley \& Sharpley, 1995; Smith, 1996; Teye, 1988).

The hypothesis that tourists and visitors are sensible and logical consumers, who move through the decision-making process by balancing utilities against costs, supposes that risks connected with political instability, war, conflict, and violence at a certain place or a destination will result in changing 
the destination image as being unsafe to safe. This hypothesis is supported and maintained by the work of many authors and writers (Aziz, 1995; Enders \& Sandler, 1991; Enders, Sandler \& Parise, 1992; Gu \& Martin, 1992; Mansfeld, 1996; Wahab, 1995).

But the essential question here is whether unstable politics or war zone locations can be, one way or another, an impetus rather than an obstacle to visiting a given destination. Hall and O'Sullivan (1996) argued that "at sites where political unrest is something of the past then such places may possess a 'curiosity' factor, whereby visitors are fascinated in seeing a place they may have seen or read about during a period of political turbulence, which is now not dangerous and safe to visit" (p. 118). However, contrary to Hall and O'Sullivan, there has long been tourism to destinations of current conflict. There are several examples of places that support this statement. In early 1990s Time Magazine described an "explosion of tourism" to the then troubled Belfast:

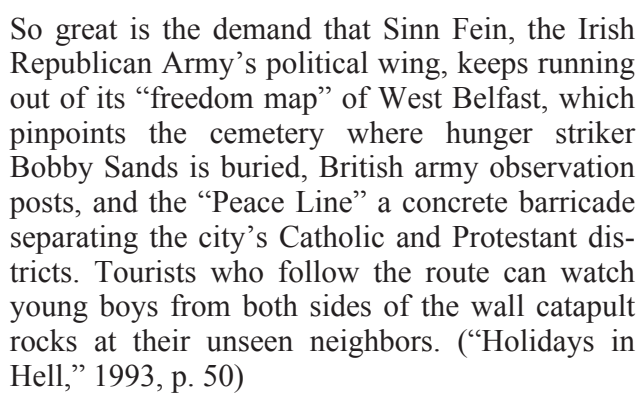

It seems that tourists are willing to pay in order to be taken into "war zones" to unstable and possibly dangerous places and to be shown things that are not propagated by the media (where media and communications are seen to be one-sided or lacking balance) that trigger their curiosity and provide them with a unique experience.

Going on a tour in a given destination organized by official or unofficial representatives of one of the aggressors, tourists are, in effect, a "captive audience." They are told and shown things that their hosts have carefully selected in order to further their political goals. Once tourists go home, the tourists may spread around a certain political agenda to their relatives and friends. Although circumstances differ significantly, tourism emerges as a political tool. During the early 1970 s, the very encouragement of tourism to the Philippines was the government's way of legitimizing martial law and presenting it as a necessary tool in making the country a safe and pleasant destination. Thus, tourism became an important component of the country's domestic policy (Richter, 1980, pp. 355-356).

Tourism also became a political tool in Tibet, but of a different sort. The declaration of martial law in March 1989 in Lhasa interrupted the nationalist unrest that began in 1987. Tibet's fledging tourism industry suffered a severe blow as a result of martial law; however, the most noteworthy effect of the unrest was the formation of a secret network of tourists who gathered information on human rights problems in order to carry the Tibetans' message to the rest of the world. Schwartz (1991, p. 599), who spent a total of 8 months in Lhasa where he collected information as a participant-observer, provides a fascinating and informative "insider's" view of the change in the nature of the tourists, which he calls the "politicization of the role of traveler" (p. 599). During the unrest, journalists were not allowed to enter the country and tourists became the only source of information about the turmoil in Tibet. Tourists both witnessed and photographed demonstrations in which civilians were shot and killed by police. These events clearly demonstrate that the opportunity to witness events in another country - afforded by tourism - can be utilized as a political tool involving information gathering and communication of political activities on behalf of those trapped and brutalized by it. It is conceivable elsewhere in countries such as Zimbabwe, Burma, and recently Iran.

Finally (although there are many more cases), Pitts (1996) refers to the "conflict or war tourist" (p. 221), coming to Mexico at a time of a sharp decline in domestic and international tourism in the wake of the 1994 armed rebellion against the Mexican government in the southern state of Chiapas. "Just like drivers on the interstate stretching their necks trying to get a glimpse of "what happened' at a wreck scene, these individuals wanted to be a part of the action" (p. 221), and to "enjoy the thrill of political violence" (p. 224). However, these onlookers certainly do not want to be a part of the action; they want to view the results of the action, which is absolutely not the same. The Mexican tourism industry adapted quickly to this trend. 
Mihalic (1996) quotes a Mexican tourist brochure that promises that "if you are lucky, you may be able to see the (Zapatista) rebels" (p. 234).

\section{Geopolitical History of Palestine}

Palestine is situated on the crossroads between three continents: Europe, Africa, and Asia. It is well thought-out the cradle of civilizations and a site of the world's three religions (Alavi \& Yasin, 2000). Table 1 provides a summary of the geopolitical history of Palestine since 1917.

\section{Palestine in Transition}

Since the Peace Accord in 1991 between Israel and Palestine in Madrid and the establishment of the Palestinian National Authority in 1993, a number of necessary steps were carried out to encourage and support tourism. One of them was the establishment of the Palestinian Ministry of Tourism and Antiquities. The tourism sector has always been a leading sector in the Palestinian economy and a crucial income generating industry accounting for $15.2 \%$ of GDP in 2004, and a job generator either through direct employment in the tourism field or indirect employment in other related fields accounting for $19.9 \%$ in 2004 (UNCTAD, 2005, as cited in Zoughbi-Janineh, 2009). However, despite the essential part that pilgrimage has played in the tourism industry in Palestine, most of money earned in the Holy Land finds its way into the Israeli economy. Therefore, it is very important to stress the importance of the Palestinian tourism industry and propose solutions for its reactivation and further development.

The Christian sacred sites in Palestine are located in Bethlehem, Jericho, and East Jerusalem. Bethlehem is located $10 \mathrm{~km}$ south of Jerusalem. Christian sites in Bethlehem are the Basilica and Grotto of the Nativity, which are sacred for Catholics, Orthodox, and Armenians, and all have ownership rights in the church. In addition, sacred sites in Bethlehem include the Church of St. Catherine, St. Jerome Church, Milk Grotto, and the pilgrimage site of Shepherds' Field. Bethlehem is the only important pilgrimage site ruled by the Palestinian National Authority (Kliot \& CollinsKreiner, 2003).

The Biblical name for Jericho "city of palm trees" (Ariha in Arabic) indicates the striking

Table 1

Geopolitical History of Palestine 1917-: Key Dates and Events

1917 Great Britain, during the First World War, issues the Balfour Declaration, promising a Jewish national home in Palestine, with respect for the rights of non-Jewish Palestinians.

1922 After the Ottoman Empire is defeated in World War I, the League of Nations confirms British mandates over Iraq and Palestine. Transjordan is separated from the Palestine Mandate and becomes an autonomous kingdom.

1936 Palestinian Arabs demand a halt to Jewish immigration and a ban on land sales to Jews. British soldiers endeavor to assert control, but violence continues. Great Britain supported a policy in favor of Zionism against indigenous Palestinians Arabs who, although representing $90 \%$ of the population in 1920 s, were simply referred as the "non-Jewish community." The Peel Commission recommends partition of Palestine between Arabs and Jews.

1939 Britain announces severe restrictions in Jewish immigration and land purchases in Palestine. Violence erupted from Jewish militants.

1947 November 29th the UN General Assembly approved a Resolution 181. The Jewish state was awarded 56.5\% of the territory of Palestine and the Arab state $42.9 \%$. The Zionist policies were victorious. They launched a movement of terror known by the code name "Plan C" (in Hebrew "Tochnit Gimmel"). Attacks against the Palestinian people become frequent but were mounted by British troops.

1948 A large-scale offensive was launched by the Zionist under Plan D in April 1948 throughout Palestine. The Zionist War was accompanied by the systematic ethnic cleansing of Palestinian towns and villages. The British mandate over Palestine terminates. By the times of the declaration of the establishment of the State of Israel, some 350,000 Palestinians had become refugees, followed by 500,000 additional refugees in the following months. Arab armies attack and Israel prevails. What had been Palestine was divided into three parts: Israel; areas annexed by the Kingdom of Jordan; and the Gaza strip, ruled by Egypt.

1967 Egypt blockades the Straits of Tiran, and Arab forces make threatening moves. Israel launches preemptive attacks on Jordan, Syria, Iraq, and Jordan. The whole of historic Palestine fell into the Jewish hands; Israel occupies the West Bank, Gaza, the Sinai, and the Golan Heights.

1987 On December 1987, the first Palestinian uprising (Intifada) erupted.

Sources: Carter (2006); Isaac and Platenkamp (2010). 
contrast the oasis makes to the surrounding desert; luxuriant greenery and fragrant flowers flourish here; its subtropical climate makes it an extraordinary garden, ideal for winter vacation, when wealthy families from Jerusalem, Ramallah, and Bethlehem come to enjoy the warmth. Situated on the west bank of the Jordan valley, $8 \mathrm{~km}$ north of the Dead Sea, Jericho owes its fertility to cool, abundant springs. Dating back more than 10,000 years, Jericho is the oldest city and the oldest continuously inhabited site in the world. Its walls and towers were built 4,000 years before the pyramids of Egypt. Some of the world's most important historical sites are concentrated in a $15-\mathrm{km}^{2}$ area, in and around the city. There are at least four different historical Jerichos: Ancient Jericho, "Tel alSultan," Hellenistic-Roman Jericho Herod's winter Palace "Tulul Abu al-Alaieq," Byzantine-Moslem Jericho, and modern Jericho. Another interesting site is the Monastery of the Qurantul (the Forty). The monastery, perched on the side of Temptation, offers a stunning panorama of the Dead Sea, Jordan Valley, and Jericho. Tradition has it that this mountain was where Jesus fasted for 40 days and was tempted by the devil. Hisham's Palace, in the heart of hunting and farmland, was one of the most impressive country residences of the Omayyad period, so archaeologists call it "the Versailles of the Middle East" (Alternative Tourism Group [ATG], 2008).

The political instability of the Holy Land, the Palestinian-Israeli conflict, and the eruption of the second uprising in October 2000 (in Arabic, Al-Aqsa Intifada), in particular, have resulted in an absolute decline in tourist flows traveling to the Holy Land. Tourists and pilgrims alike are reluctant to travel to places that often appear on TV screens or in the newspapers as arenas for violent conflicts. Even devout Christians are reluctant to visit destinations as unstable as Israel and Palestine. There is no doubt that the political tensions in the Holy Land between Israelis and Palestinians all have a very negative impact on would-be pilgrims. Also, the description of the pilgrimage destinations as being overcrowded added to the negative image of the Holy Land. For many religious Catholics there was the safe alternative of a pilgrimage trip to Rome or Lourdes, and the Holy Land could be avoided (Collins-Kreiner et al., 2005). But are these really alternatives?

The outbreak of the second Palestinian uprising Intifada introduced Palestine to a reality of sporadic political violence, tension, and instability. The impact of the crisis was felt immediately as visitors to Palestine decreased by almost $90 \%$; in 2002, arrivals to Palestine were at a record low of only 8,045 visitors (down from 843,718 visitors in 2000) (Khoury, 2008). These statistics suggest that a new tourist phenomenon has emerged whereby certain tourists and visitors come to Palestine in order to show their solidarity and support for each of the violent sides residing in it (see Brin, 2006; Isaac, 2010a).

\section{Pilgrimage Tourism}

Pilgrimage is a well-known phenomenon in religion and culture and it exists in all the main religious of the world: Buddhism, Hinduism, Islam, Judaism, and Christianity. Pilgrimage is defined as "a journey resulting from religious causes, externally to a holy site, and internally for spiritual purposes and internal understanding" (Barber, 1993, p. 1). Pilgrimage, whether traditional and religious or modern and secular, is experiencing resurgence around the world and long-established shrines still act as magnets for those in search of spiritual goals (Digance, 2003). Discussion of the pilgrimage metaphor has produced many intriguing debates in tourism but too few discussions on the pilgrimage itself (Attix, 2002; Cohen, 1979; Graburn, 1989; Vukonić, 1996).

A typical pilgrim-tourist spends 9 to 10 days in the Holy Land and an average itinerary includes 4 to 5 days in Jerusalem (including visits to Bethlehem, Jericho, and the Dead sea) and 3 or 4 days in northern Israel, where the focus is on Nazareth, the Sea of Galilee, and other sites (Israel, Ministry of Tourism, 2003). Specific sites are visited depending on the religious denomination of the pilgrims as different churches have their own sacred sites. Christian pilgrimage is not a unified phenomenon (Fleischer, 2000). There are differences between the Protestants and the Catholics in their needs and therefore in their behavior (Bowman, 1991). These differences are 
manifested in different tourist activities, motivations, and expectations.

As an indication of this increase in pilgrimage tourism, the Israeli Tourism Ministry reported that between January and July 2008 visitors to Israel increased by $40 \%$ over 1.7 million visitors compared with same period in 2007. A total 260,000 people visited Israel in July alone (Tours in English, 2008).

Apart from for the above statistics, alas there are no readily obtainable hard data concerning the number of tourists visiting the Palestine. Israel does not carry out such statistics. Such statistics are hard to collect in the first place for the reason that there are no Palestinian Border controls at the checkpoints into major Palestinian cities, and of course the Israeli government controls Ben Gurion airport (Tel Aviv) and the borders with Egypt and Jordan.

Nowadays, Palestine's tourism industry is controlled by Israel. Israel has a stranglehold on the flow of international tourists, starting from visa issuing, flights, lodging, to Israeli guides and tours within the country. This has resulted in half empty hotels in major Palestinian cities while in Israel it has been difficult to make a reservation during the summer. It seems obvious that the situation will not improve unless the closures and checkpoints are lifted to allow free flow and movement of people between Israel and Palestine, and between cities in the West Bank (Al-Rimmawi, 2003).

\section{The Dark Tourism Potential in Palestine: The Separation Wall}

In the summer of 2002, the State of Israel approved construction of the Separation Wall to separate the West Bank from Israel in order to prevent the uncontrolled entry of Palestinians into Israel (Kliot \& Charney, 2006). In most areas, the Separation Wall comprises an electronic fence with dirt paths, barbed wire fences, and trenches on both sides, at an average of width of $60 \mathrm{~m}$. In some areas, the Separation Wall is 6 to $8 \mathrm{~m}$ high, twice the height of the Berlin Wall. The Separation Wall erases agricultural fields and houses and it is 759 km (Aguirre, 2007; Applied Research Institute, 2005) long-five times longer than the Berlin Wall. A total of 38 villages and towns find themselves completely separated from their agricultural lands, unable to farm them. Some 50,000 Palestinians are trapped between the border and the Separation Wall, facing alienation and impoverishment from their land and water, and eventual transfer (United Nations [UN], 2005).

In the north, the Separation Wall not only seals the separation of Bethlehem from Jerusalem but prevents the urban growth of Bethlehem northwards. The western section of the Separation Wall has devastated the governorate of Bethlehem. Approximately $64 \mathrm{~km}$ including some of the most fertile land in the governorate and nine Palestinian communities with approximately 21,000 residents have been isolated, encountering reduced access to Bethlehem city, the major services center for health, education, markets, and trade (B'Tselem, 2008; United Nations Office for the Coordination of Humanitarian Affairs [UNOCHA], 2009). Urban Bethlehem is surrounded by a combination of nine Israeli settlements, a stretch of the Separation Wall, roads restricted to Israelis, and a multitude of checkpoints, earth mounds, and roadblocks. Approximately 78 physical obstacles surround Bethlehem today (see, UNOCHA, 2009).

Recently published academic studies tackle the geopolitical and security measures consequences of the Separation Wall (Folman, 2004; Khamaisi, 2006; Michael \& Ramon, 2004; Soffer \& Polack, 2003). Kimhi (2006) predicted possible future effects of the Separation Wall on Jerusalem and its inhabitants, creating four theoretical options for how it could serve in the future as part of joint agreement for setting the final borders. The report of the Humanitarian and Emergency Policy Group of the Local Aid Coordination Committee (2003) concentrated on the humanitarian implications of the Separation Wall for Palestinian communities on the West Bank.

On July 9, 2004, the International Court of Justice, in The Hague, gave its advisory opinion on the question of the legality of the Separation Wall being built by Israel on Palestinian land and ordered it to be dismantled. The opinion was given pursuant to the request of the UN General Assembly of December 3, 2004. Nonetheless, Israel refuses to comply with this decision.

B'Tselem (2008), the Israeli Information Center for Human Rights in the Occupied Territories, 
states that as of December 2007, there are 99 permanent Israeli checkpoints throughout the West Bank. The UNOCHA also lists the number of flying (surprise) checkpoints, which varied from an average of 69 a week in October 2007 to 141 a week in May 2007 (UNOCHA, 2007). These figures in themselves demonstrate how arbitrary and unpredictable these barriers to movement are. These restrictions on movements, such as checkpoints, closed roads, and closures enforced, must be seen in relation to the relative mobility that they create for Israeli settlers living illegally on Palestinian land:

Israeli settlements in the West Bank are dormitory suburbs, reliant on roads connecting them with the urban centers of Israel proper. So-called "bypass" roads were a feature of the Oslo accord. The Israeli government was allowed (with specially allocated American money) to construct a network of fast, wide security roads that bypass Arab towns and connect the settlements to Israel. The bypass roads, some still in the building would become a massive system of twenty-nine highways spanning four hundred and fifty kilometres which Palestinians cannot use. They allow four hundred thousand Jews living in land occupied in 1967 to have freedom of movement. About three million Palestinians are left locked into isolated enclaves. (Weizman, 2002)

There is an extensive body of literature investigating the impact of political instability and war on tourism; however, there is a limited body of literature on the impact of political instability and war on the tourist's perceived risk studies of the consequent decision-making process when contemplating a travel destination (see, e.g., Lepp \& Gibson, 2003; Reisinger \& Mavondo, 2005; Sönmez, 1998; Sönmez \& Graefe, 1998). The literature shows that gender is an important factor influencing travel and risk perceptions and tolerance (Carr, 2001). Women are more concerned with travel risks than men (e.g., Lepp \& Gibson, 2003; Reisinger \& Crotts, 2010) and more vulnerable to risk than men (Gibson \& Jordan, 1998a, 1998b). Similar gender-based differences regarding risk-taking was suggested by Arch (1993, p. 4). It does not follow, however, that well-traveled, independent males are more likely to willingly seek dark or politically unstable destinations than others.
Richter (1980, p. 330) explained that specific itineraries might be viewed as representing ideological values of the tourists and their political convictions and beliefs. It might be suggested that tourists who go on a holiday to a country that is experiencing war and political instability, a destination associated with death, suffering and violence, are themselves politically "natured." They might support one side or another of the conflict, or might be intrigued by the very conflict - its origins, causes, and backgrounds, its current implications on local populations, and its presence in everyday life. Tourists in this case are witnessing history in the making where danger is the central attraction, providing an edge to the tourism experience. This aspect may match also the so-called adventure tourism. Adventure tourism has increased rapidly in recent years, becoming a major niche within the special interest tourism sector. It is also said to be the fastest growing outdoor tourism market segment, with an estimated annual growth of $15 \%$ (Buckly, 2007; Burak, 1998; Cater, 2005).

Analyzing the literature and a variety of features of "dark" tourism as well as the ongoing issues concerning the Separation Wall, it could be concluded that there is a wide range of motivations to visit the Separation Wall in the West Bank, and in Bethlehem in particular. Notwithstanding the variety of angles on dark tourism in the literature (e.g., Bly, 2003; Miles, 2002; Shapley, 2005; Stone, 2006; Stone \& Sharpley, 2008), the main inquiry of who are tourists who search for such dark sites and why they are attracted to them remains unresolved.

Yet, as symbols of conflict and even in representing the restrictions of Palestinian's lives, such sites can certainly be considered part of the dark tourism trend. "Dicing with death" is one way of illustrating this form of tourism, in which putting one's self in a position of danger or risk - potentially facing death - is part of the demand. From that viewpoint, war zone tours could be thought of as the latest in extreme sports (Sharpley, cited in Kroitoru, 2009).

Thus, visitors to the Separation Wall in Bethlehem may be considered a type of "dark" tourist. During a tour in Bethlehem, visitors are attracted to witnessing the difficulties (Israeli checkpoints, borders, and Walls), and stories of suffering of the Palestinian families. Visits are made to Palestinian 
refugee camps (three refugee camps, in total) in Bethlehem where visitors are introduced to the existing conditions of refugees and discussions are also held on aspects of the "right of return," the legitimacy, and recognition of the Palestinian exodus in 1948 and 1967-also known as "Nakba" meaning the "disaster," "catastrophe," or "cataclysm" (Cleavland, 2004; personal communication with Kokaly, 2009). The "Nakba" refers to the mass destruction and depopulation of Palestine in 1948, during the war that led to the founding of the state of Israel. During the "Nakba" about three quarters of a million Palestinian were forced to leave their homes and some 500 Palestinian localities were destroyed. Palestinians who were expelled during the "Nakba" have since grown to become the largest refugee population in the world according to the UN. In addition, within Israel a quarter of a million Palestinians live as "internally displaced" refugees - citizens in their country but defined by law as "absentees" denied the right to their land, homes, and property (Carter, 2006; Halper, 2008; Isaac \& Platenkamp, 2010). The Separation Wall impacts Palestinian life through the destruction of the social and spatial environment. The confiscation of land, the destruction of visual perspective, the closure of enclaves, the denial of privacy, the destruction of landscape, and the systematic control of Palestinian places of memories and social meanings can be described as acts of "spaciocide" and "urbicide" (massive destruction and disorganization of spaces and cities) (Coward, 2007; Graham, 2004; Hanafi, 2009; Weizman, 2007). If you ask Palestinians about these Walls, they reflect that they are not the worst aspect of their situation, because the Israelis are constantly confiscating land on the inward side.

The Palestinian people were directly faced with horrifying consequences of the building of the Separation Wall in Bethlehem. For example, the consequences for the family of Claire Anastas, a member of the Arab Educational Institute in Bethlehem, were dreadful. Her house was destined to be surrounded by the Wall on three sides (Van Teeffelen, 2007). The entrance to Bethlehem used to be one of the liveliest areas in Bethlehem with many shops, restaurants, souvenir shops, and nightlife. All these places are now forms of dark tourism in Palestine. The motives that tourists visiting these places associated with suffering have may be similar to those explained by Ashworth and Hartman (2005) in relation to atrocities tourism, namely empathy, sympathy, and curiosity factors. The seeit-for-yourself dynamic is unquestionably a drawcard; academics such as Lennon and Sharpley say the trend related to an age-old, inherent interest in death and war. Some tourists want to lay a hand on the bullet holes, possibly feel the danger, and meet those battling warlords, all for themselves.

As Bowman (1992), referring not necessarily to visitors consuming dark tourism, noted: "The 'place' tourists see is not simply a reified image of their expectations or a 'real' terrain, but is the result of a dialogue between tourists and those persons and institutions which mediate between the touristic gaze and its object" (p 132).

\section{Conclusions}

This article has intended to provide new insights into the possibilities of dark tourism leveraging the Palestinian tourism industry. Relatively little attention has been paid in the academic literature to the tourism development, impediments or/and potential and growth in Palestine. For Palestine, a destination under occupation sealed off and isolated from the world and with on-going political instability filled with conflicts and violence, paying attention to these relationships is needed more than ever.

In the face of increasing academic consideration paid to dark tourism, the analysis of it has, to date, adopted largely descriptive, narrowly defined perspectives whereas questions surrounding the consumption side; "who visits and why" of dark and atrocities tourism experiences, remain largely unresolved. This article therefore, also provides some exploratory insights into the main motives of dark tourists that come to Palestine and in particular to sites connected with death and suffering.

Researchers have started to investigate both the supply and demand side of "dark tourism (e.g., Ashworth, 2003; Ashworth \& Hartmann, 2005; Bruner, 1996; Lennon \& Foley, 2000; Miles, 2002; Seaton, 1996, 2002; Teye \& Timothy, 2004). Nonetheless, there is a prerequisite to understanding issues of personal or social identity connected with visits to these places. The location of the former World Trade Center in New York has become 
an important tourist attraction that is redolent with deep meaning; the attack event of 2001 turned profane space into sacred space for Americans, creating a common sense of national identity (Timothy \& Boyd, 2006).

Questions may be asked about how dark tourism sites are supplied. Are they supplied for political reasons, for the education of the new Palestinian generations, for economic growth, or all of the three? These answers indeed require more research and investigations by Palestinian academics and different stakeholders involved in the tourism industry.

It is tourism of an apparently "dark" varietyone that stands clearly separately from its three Ss - sun-sea-sand - counterparts, that has tourists heading to Palestine, not only despite war, and conflict but because of it. Evidently, Palestine has the potential to attract tourists and it is clear from this article that Palestine has broadened its tourism base (probably informally), whether it is described as thanatourism or adventure tourism. Perhaps at best, the new form of tourism is short-lived, enabling Palestine to informally diversify its visitors and earn visitor dollars.

To conclude, tourism may be looked at as ways of bringing Palestinian society together and as to reinforce national identity and unity. Also, tourism can be seen as a tool to promote peace. Several researchers and scholars have examined the proposition that tourism has some potential to reduce tensions between divided countries (see, Butler \& Mao; S. S. Kim, Prideaux, \& Prideaux, 2007; Y. Kim \& Crompton, 1990; Waterman, 1987). Twotrack diplomacy (Y. Kim \& Crompton, 1990) was explained in Isaac's article (2010b) in the context of the Palestinian-Israeli conflict and how it worked on both, government-to-government and people-topeople relations.

This is exactly the time where Palestinian's voices, now silent and silenced, need to be heard within the tourism discourses. Edward Saïd (1974), famous for his critical analysis of western representations of the Orient in literature and music, introduced a topical debate on silenced voices. Silenced voices are voices that have been silenced or that are unable to express themselves. They are not observed in official, academic, or professional discussions. This is mostly due to the reality, of the predominant hegemonic power relations; they have been filtered out of the focus of interest in these discussions.

\section{References}

Aguirre, M. (2007, January). Middle East diplomacy: Between war and negotiations, an observer's view. Madrid: Fundación par alas Relationes Internaciónales y el Diálogo Exterior.

Alavi, J., \& Yasin, M. (2000). A systematic approach to tourism policy. Journal of Business Research, 48, 147-156.

Al-Rimmawi, H. A. (2003). Palestinian tourism: A period of transition. International Journal of Contemporary Hospitality Management, 15 (2), 76-85.

Alternative Tourism Group. (2008). Palestine and Palestinians. Beitsahour: Author.

Applied Research Institute. (2005). Geo-political conditions in Bethlehem. Jerusalem: Author.

Arch, E. C. (1993). Risk taking: A motivational basis for sex differences. Psychological Reports, 73 (1), 3-5.

Ashworth, G. J. (1996). Jewish culture and holocaust tourism: The lessons of Kraków-Kazimiez. In M. Robinson, N. Evans, \& P. Callaghan (Eds.), Tourism and culture: Towards the 21st century (pp. 1-13). Newcastle: University of Northumbria.

Ashworth, G. J. (2003). Heritage, identity and places: For tourists and host communities. In S. Singh, D. J. Timothy, \& R. K. Dowling (Eds.), Tourism in destination communities. Wallingford: CABI.

Ashworth, G. J., \& Hartmann, R. (Eds.). (2005). Horror and human tragedy revisited: The management of sites of atrocities for tourism. New York: Cognizant Communication Corporation.

Attix, A. A. (2002). New age-oriented special interest travel: An exploratory study. Tourism Recreation Research, 27(2), 51-58.

Aziz, A. (1995). Understanding terrorist attacks in Egypt. Tourism Management, 16, 91-95.

Barber, R. (1993). Pilgrimages. London: The Boydell.

Beech, J. (2000). The enigma of holocaust sites as tourist attractions: The case of Buchenwald. Managing Leisure, $5,29-41$.

Beirman, D. (2003). United States: September 11, 2001 terrorist attack. The impact on American and global tourism. In D. Beirman (Ed.), Restoring tourism destinations in crisis: A strategic marketing approach (pp. 43-68). Oxon: CABI Publishing.

Blom, T. (2000). Morbid tourism: A postmodern market niche with an example from Althorpe. Norwegian Journal of Geography, 54, 29-36.

Bly, L. (2003). Disaster strikes, tourists follows. Retrieved from http: //www.usatoday.com/travelvacations/destina tions/.../2002-08-30disaster-tourism.html

Bowman, G. (1991). Christian ideology and the image of a Holy Land: The place of Jerusalem in the various Christianities. In M. J. Sallnow \& J. Ead (Eds.), Contesting the sacred: The anthropology of Christian pilgrimage (pp. 98-121). London: Routeledge. 
Bowman, G. (1992). Passion, power and politics in a Palestinian tourist market. In T. Selwyn (Ed.), The tourist image: Myths and myth making in tourism. New York and London: Wiley.

Brin, E. (2006). Politically-oriented tourism in Jerusalem. Tourist Studies, 6 (3), 215-243.

Bruner, E. (1996). Tourism in Ghana: The representation of slavery and the return of Black Dispora. American Anthropologist, 98, 397-415.

B'Tselem. (2008). The separation barrier. The Israeli Information Center for Human Rights in the Occupied Territories. Retrieved May 11, 2008 from http://www. btselem.org/English/Separation\%5FBarrier/

Buckly, R. C. (2007). Adventure tourism products: Price, duration, size, skills, and remoteness. Tourism Management, 28, 1428-1433.

Burak, P. G. (1998). The nature of adventure tourism in soft adventure tourism. Ph.D. dissertation, University of Alberta, Edmondtons.

Butler, R., \& Mao, B. (1995). Tourism between divided quasi-states: International domestic or what? In R. Butler \& D. Pearce (Eds.), Change in tourism: Peoples, places, processes (pp. 92-113). London: Routledge.

Carr, N. (2001). An exploratory study of gendered differences in young tourist's perception of danger within London. Tourism Management, 22, 565-570.

Carter, J. (2006). Palestine: Peace not apartheid. London: Simon \& Schuster.

Cater, C. (2005). Looking the part: The relationship between adventure tourism and the outdoor fashion industry. In C. S. Page \& L. Aitken (Eds.), Taking tourism to the limits. London: Elsevier.

Clarke, R. (2000). Self-presentation in a contested city: Palestinian and Israeli political tourism in Hebron. Anthropology Today, 16(5), 61-85.

Cleavland, W. L. (2004). A history of the modern Middle East. Boulder: Westview Press.

Cohen, E. (1979). A phenomenology of tourism experience. Sociology, 13(2), 179-201.

Collins-Kreiner, N., Kliot, N., Mansfeld, Y., \& Sagi, K. (Eds.). (2005). Christian tourism to the Holy Land. Hampshire: Ashgate.

Cook, W. J. (1990). The effect of terrorism on executive's willingness to travel internationally. Unpublished Ph.D. thesis, City University of New York.

Coward, M. (2007). Urbicide reconsidered. Theory \& Event, $10(2)$.

Daher, R. (2006). (Ed.) Tourism in the Middle East. Clevedon: Channel View publications.

Dann, G. (1998). The dark side of tourism. Etuds et Rapports, Série L. Aix-en-Provence, Centre International de Recherches et d'Etudes Touristiques.

Dann, G., \& Seaton, A. (2001). Slavery, contested heritage and thanatourism. Binghamton, NY: Haworth Hospitality Press.

Digance, J. (2003). Pilgrimage at contested sites. Annals of Tourism Research, 30(1), 143-159.

Enders, W., \& Sandler, T. (1991). Causality between transnational terrorism and tourism: The case of Spain. Terrorism, 14, 49-58.

Enders, W., Sandler, T., \& Parise, G. F. (1992). An econometric analysis of the impact of terrorism on tourism. Kyklos, 45, 531-554.

Fleischer, A. (2000). The tourist behind the pilgrim in the Holy Land. Hospitality Management, 19, 311-326.

Foley, M., \& Lennon, J. (1996a). JFK and dark tourism: A fascination with assassination. International Journal of Heritage Studies, 2, 198-211.

Foley, M., \& Lennon, J. (1996b). Editorial: Heart of darkness. International Journal of Heritage Studies, 2, 195-197.

Folman, Y. (2004). The story of the security fence: Life repudiation indeed? Jerusalem: Carmel (in Hebrew).

Gartner, W. C., \& Shen, J. (1992). The impact of Tiananmen Square on China's tourism image. Journal of Travel Research, 30(4), 47-52.

Gibson, H., \& Jordan, F. (1998a). Traveling solo: A crosscultural study of British and American women aged 30-50. Paper presented at the 4th International Conference of the Leisure Studies Association, Leeds, UK.

Gibson, H., \& Jordan, F. (1998b). Shirley Valentine lives! The experience of solo women travelers. Paper presented at the 5th Congress of the World Leisure and Recreation Association, Sao Paulo, Brazil.

Graburn, N. H. (1989). Tourism: The sacred journey. In V. L. Smith (Ed.), Hosts and guests: The anthropology of tourism. Philadelphia: University of Pennsylvania Press

Graham, S. (2004). Constructing urbicide by bulldozer in the occupied territories. In S. Graham (Ed.), Cities, war and terrorism: Towards an urban geopolitics. Oxford: Blackwell.

Gu, Z., \& Martin, T. L. (1992). Terrorism, seasonality and international air tourist arrivals in central Florida: An empirical analysis. Journal of Travel and Tourism Marketing 1, 3-15.

Hall, C. M. (1994). Tourism and politics: Policy, power and place. New York: Wiley.

Hall, C. M., \& O’Sullivan, V. (1996). Tourism, political stability and violence. In A. Pizam \& Y. Mansfeld (Eds.), Tourism, crime and international security issues. New York: Wiley.

Halper, J. (2008). An Israeli in Palestine: Resisting dispossession, redeeming Israel. London: Pluto.

Hanafi, S. (2009). Sapcio-cide: Colonial politics, invisibility and rezoning in Palestinian territory. Contemporary Arab Affairs, 2(1), 106-121.

Harvey, D. (1995). From space to place and back again: Reflections on the conditions of postmodernity. In J. Bird, B. Curtis, T. Putnam, G. Robertson, \& L. Tickner (Eds.), Mapping the futures: Local cultures, global change (pp. 3-29). London: Routledge.

Holidays in hell. (1993, August 23). Time Magazine, 142(8), 50.

Humanitarian and Emergency Policy Group of the Local Aid Coordination Committee. (2003). The impact of 
Israel's separation barrier on the affected West Bank communities. United Nations.

Irvine, W., \& Anderson, A. R. (2006). The effect of disaster on peripheral tourism places and the disaffection of prospective visitors. In Y. Masfeld \& A. Pizam (Eds.), Tourism, security and safety from theory to practice (pp. 169-186). Oxford: Butterworth-Heinemann.

Isaac, R. K. (2008). Master of Arts in pilgrims and tourism. Tourism and Hospitality Planning \& Development, 5(1), 73-76.

Isaac, R. K. (2009). Alternative tourism: Can the segregation wall in Bethlehem be a tourist attraction? Tourism, Hospitality, Planning and Development, 6(3), 24 $\overline{47-254 .}$

Isaac, R. K. (2010a). Alternative tourism: New forms of tourism in Bethlehem for the Palestinian tourism industry. Current Issues in Tourism, 13(1), 21-36.

Isaac, R. K. (2010b). Moving from pilgrimage to responsible tourism the case of Palestine. Current Issues in Tourism, 13(6), 579-590.

Isaac, R. K., \& Platenkamp, V. (2010). Volunteer tourism in Palestine: A normative perspective. In O. Moufakkir \& I. Kelly (Eds.), Tourism, progress and peace (pp. 148161). Wallingford: CAB International.

Israel Ministry of Tourism. (2003). Survey of incoming tourists in 2002 (in Hebrew). Jerusalem: Author.

Khamaisi, R. (2006). The impact of the separation fence on the population in Israel: Initial observation. Jerusalem: The Floersheimer Institute for Policy Studies.

Khoury, S. (2008). Tourism development and destination marketing under occupation: The case of destination Palestine. Unpublished M.A. dissertation, University of London Metropolitan.

Kim, S. S., Prideaux, B., \& Prideaux, J. (2007). Using tourism to promote peace on the Korean Peninsula. Annals of Tourism Research, 34(2), 291-309.

Kim, Y., \& Crompton, J. (1990). Role of tourism in unifying the two Koreas. Annals of Tourism Research, 17(3), 353-366.

Kimhi, I. (2006). The security fence in Jerusalem: Its impact on the city residents. Jerusalem: The Jerusalem Institute for Israel Studies.

Kliot, N., \& Charney, Y. (2006). The geography of suicide terrorism in Israel. GeoJournal, 66, 353-373.

Kliot, N., \& Collins-Kreiner, N. (2003). Wait for us-we're not ready yet: Holy Land preparations for the new millennium-the year 2000. Current Issues in Tourism, 6(2), $119-146$.

Kolby, P. S. (1983). Christians and the Christian sacred sites in the Galilee. In A. Soffer, A. Shmueli, \& N. Kliot (Eds.), The lands of Galilee (pp. 521-528). Haifa: Haifa University.

Kroitoru, H. (2008). Quenching the thirst for war. Retrieved January 20, 2009 from http://themedialine.org/news/ news_detail.asp?NewsID $=23298$

Lennon, J., \& Foley, M. (2000). Dark tourism: The attraction of death and disaster. London: Continuum.

Lepp, A., \& Gibson, H. (2003). Tourist roles, perceived risk and international tourism. Annals of Tourism Research, 30(3), 606-624.
Mansfeld, Y. (1996). Wars, tourism and the "Middle East" factor. In A. Pizam \& Y. Mansfeld (Eds.), Tourism, crime and international security issues. New York: Wiley.

Mansfeld, Y. (1999). Cycles of war, terror and peace: Determinants and management of crisis and recovery of the tourism industry. Journal of Travel Research, 38, 30-36.

Mansfeld, Y., \& Kliot, N. (1996). The tourism industry in the Partitioned Island of Cyprus. In A. Pizam \& Y. Mansfeld (Eds.), Tourism, crime and international security issues. New York: Wiley.

Michael, K., \& Ramon, A. (2004). Jerusalem surrounded by a fence. Jerusalem: Jerusalem Institute for Research (in Hebrew).

Mihalic, T. (1996). Tourism and warfare: The case of Slovenia. In A. Pizam \& Y. Mansfeld (Eds.), Tourism, crime and international security issues. New York: Wiley.

Miles, W. (2002). Auschwitz: Museum interpretation and darker tourism, Annals of Tourism Research, 29, 11751178 .

Milman, A., \& Bach, S. (1999). The impact of security devices on tourists' perceived safety: The central Florida example. Journal of Hospitality and Tourism Research, 23(4), 371-386

Mitchell, V. W., \& Vasso, V. (1997). Perceived risk and risk reductions in holiday purchase: A cross-cultural and gender analysis. Journal of Euromarketing, 6(3), 47-97.

Muzaini, H., Teo, P., \& Yeoh, B. (2007). Intimations of postmodernity in dark tourism: The fate of history at Fort Siloso, Singapore. Journal of Tourism and Cultural Change, 5, $28-45$.

Panic-Kombol, T. (1996). The cultural heritage of Croatian cities as a tourism potential. World Leisure and Recreation, 38(1), 21-25.

Pitts, W. J. (1996). Uprising in Chiapas, Mexico: Zapata lives, tourism falters. In A. Pizam \& Y. Mansfeld (Eds.), Tourism, crime and international security issues. New York: Wiley.

Pizam, A., Tarlow, P., \& Bloom, J. (1997). Making tourists feel safe: Whose responsibility is it? Journal of Travel Research, 36(1), 23-28.

Poria, Y., \& Ashworth, G. (2009). Heritage attractions: A resource for conflicts. Annals of Tourism Research, 36(3), 522-525.

Reisinger, Y., \& Crotts, J. C. (2010). The influence of gender on travel risk perceptions, safety and travel intentions. Tourism Analysis, 14, 793-807.

Reisinger, Y., \& Mavando, F. (2005). Travel anxiety and intentions to travel internationally: Implications of travel risk perception. Journal of Travel Research, 43(3), 212-225.

Richter, L. K. (1980). The political uses of tourism: A Philippine case study. The Journal of Developing Area, 14(2), 237-357.

Richter, L. K. (1992). Political instability and tourism in the Third World. In D. Harrison (Ed.), Tourism and the less developed countries (pp. 35-46). London: Belhaven. 
Richter, L. K., \& Waugh, J. R. (1986). Terrorism and tourism as logical companions. Tourism Management, 7(4), 230-238.

Roehl, W. S. (1995). The June 4, 1989, Tiananmen Square incident and Chinese tourism. In A. A. Lew \& L. Yu (Eds.), Tourism in China: Geographic, political and economic perspectives. Boulder, CO: West View Press.

Roehl, W. S., \& Fesenmaier, D. R. (1992). Risk perceptions and leisure travel: An exploratory analysis. Journal of Travel Research, 2(4), 17-26.

Rojek, C. (1993). Ways of escape. Basingtole: Macmillan.

Rojek, C. (1997). Indexing, dragging and the social construction of tourist sights. In C. Rojek \& J. Urry (Eds.), Touring cultures: Transformations of travel and theory. London: Routledge.

Ryan, C., \& Kohli, R. (2006). The buried village, New Zealand: An example of dark tourism? Asia Pacific Journal of Tourism Research, 11, 211-226.

Saïd, E. (2003). Orientalism. London: Penguin Books. (First published 1974)

Schwartz, R. (1991). Travellers under fire: Tourists in the Tibetan uprising. Annals of Tourism Research, 18(4), 588-604.

Schiebler, S., Crofts, J., \& Hollinger, R. (1996). Florida tourists' vulnerability to crime. In A. Pizam \& Y. Mansfeld (Eds.), Tourism crime and international security issues (pp. $37-50)$. Chichester: Wiley.

Scott, R. (1988). Managing crisis in tourism: A case study of Fiji. Travel and Tourism Analyst, 6, 57-71.

Seaton, A. V. (1996). Guided by the dark: From thanatopsis to thanantourism, International Journal of Heritage Studies, 2, 234-244.

Seaton, A. V. (1999). War and thanatourism: Waterloo 1815-1914. Annals of Tourism Research, 26, 130-158.

Seaton, A. V. (2002). Thanatourism's final frontiers? Visits to cemeteries, churchyards and funerary sites as sacred and secular pilgrimage. Tourism Recreation Research, $27,73-82$

Sharpley, R. (2005). Travels to the edge of darkness: Towards a typology of dark tourism. In C. Ryan, S. Page, \& M. Aitken (Eds.), Taking tourism to the limits: Issues, concepts and management perspectives. Oxford: Elsevier.

Sharpley, R., \& Sharpley, J. (1995). Travel advice-security or politics? In Risks in Travel and Tourism, Proceedings of the Talk at the Top Conference, Ostersund, MidSweden University.

Smith, V. L. (1996). War and its tourist attraction. In A. Pizam \& Y. Mansfeld (Eds.), Tourism, crime and international security issues. New York: Wiley.

Smith, V. L. (1998). War and tourism: An American ethnography. Annals of Tourism Research, 25, 202-227.

Soffer, A., \& Polack, K. (2003). Unilateral separation of Israel from the Palestinian Authority by means of a separation fence-advantages and disadvantages. Haifa: The Geos-trategica Chair, The Center for National Security Research, Haifa University (in Hebrew).

Sönmez, S. F. (1998). Tourism, terrorism and political instability. Annals of Tourism Research, 25(2), 416-456.

Sönmez, S. F., \& Graefe, A. R. (1998). Influence of terrorism risk on foreign tourism decisions. Annals of Tourism Research, 25(1), 112-144.

Stone, P. (2006). A dark tourism spectrum: Towards a typology of death and macabre related tourist sites, attractions and exhibitions. Tourism: An Interdisciplinary International Journal, 52, 145-160.

Stone, P., \& Sharpley, R. (2008). Consuming dark tourism: A thanatological perspective. Annals of Tourism Research, 35(2), 574-595.

Strange, C., \& Kempa, A. (2003). Shades of dark tourism: Alcatraz and Robben Island. Annals of Tourism Research, 30, 386-403.

Tarlow, P. G. (2005). Dark tourism: The appealing "dark" side of tourism and more. In M. Novelli (Ed.), Niche tourism: Contemporary issues, trends and cases (pp. 47-58) . Oxford: Elsevier.

Teye, V. B. (1988). Coups d'etat and African tourism: A study of Ghana. Annals of Tourism Research, 15, 329-356.

Teye, V. B., \& Timothy, D. J. (2004). The varied colors of slave heritage in West Africa: White American stakeholders. Space and Culture, 7(2), 145-155.

Timothy, D. J. (2001). (Ed.). Tourism and political boundaries. London: Routledge.

Timothy, D. J., \& Boyd, S. W. (2006). Heritage tourism in the 21st century: Valued traditions and new perspectives. Journal of Heritage Tourism, 1(1), 1-16.

Tourism-Review.com. (2009). Adventure war zone: Someone like it hot. Retrieved October 10, 2009 from http://www.tourism-review.com/travel-tourism-maga zine.php

Tours in English. (2008). Tourism boom in Israel: But what about Palestine? Retrieved September 1, 2008 from http://www.toursinenglish.com/2007/01/tourism-boomin-israel-bethlehem-tours.html

Tunbridge, J., \& Ashworth, G. J. (1996). Dissonant heritage: Managing the past as a resource in conflict. Chichester: John Wiley.

United Nations. (2005). The humanitarian impact of the West Bank barrier on Palestinian communities. Jerusalem: OCHA.

United Nations Office for the Coordination of Humanitarian Affairs. (2007). Closure update- Occupied Palestinian Territory-October 2007. Retrieved October 10, 2009, from http://www.ochaopt.org/documents/ClosureUpdate October2007.pdf

United Nations Office for the Coordination of Humanitarian Affairs. (2009). Special focus: Shrinking space: Urban contraction and rural fragmentation in the Bethkehem Governorate. Retrieved December 2009 from http:// www.ochaopt.org/documents/ocha_opt_bethlehem shrinking_space_may_2009_english.pdf

Uriely, N. (2005). The tourist experience: Conceptual developments. Annals of Tourism Research, 32(1), 199-216.

Urry, J. (1990). The tourist gaze: Leisure and travel in contemporary societies. London: Sage Publications.

Uzell, D. (1989). The hot interpretation of War and conflict. In D. Uzell (Ed.), Heritage interpretation volume 1: The natural and built environment. London: Routledge. 
Van Teeffelen, T. (Ed.). (2007). Challenging the wall: Towards a pedagogy of hope (Culture and Palestine Series). Bethlehem: Arab Educational Institute.

Vukonić, B. (1996). Tourism and religion. London: Elsevier Science Ltd.

Wahab, S. (1995). Terrorism: A challenge to tourism. In Risks in Travel and Tourism, Proceedings of the Talk at the Top Conference, Ostersund, Mid- Sweden University.

Wahab, S. (2000). Middle East. In A. Lockwood \& S. Medlik (Eds.), Tourism and hospitality in the 21st century. Oxford: Butterworth-Heinemann.

Waterman, S. (1987). Partitioned states. Political Geography Quarterly, 6(2), 151-171.

Weizman, E. (2002). The politics of verticality: 10. Roadsover and under. Retrieved October 10, 2009, from http:// opendemocracy.net/conflict-politicsverticality/article 809.jsp

Weizman, E. (2007). Hollow land: Israel's architecture of occupation. London: Verso.
Wieviorka, M. (1994). The making of terrorism. Chicago: The University of Chicago Press.

Wight, C., \& Lennon, J. (2002). Towards an understanding of visitor perceptions of "dark" attractions: The case of the Imperial War museum of North Manchester. Journal of Hospitality and Tourism, 2(2), 105-122.

Wight, C., \& Lennon, J. (2007). Selective interpretation and eclectic human heritage. Lithuanian Tourism Management, $2,105-122$.

Wilson, J. Z. (2004). Dark tourism and the celebrity prisoner: Front and back regions in representations of an Australian historical prison, Journal of Australian Studies, 28(82), 1-13).

Zoughbi-Janineh, C. (2009). The development of rural tourism in the hidden parts of Palestine: A case study from the Bethlehem district. In R. Isaac, V. Platenkamp, \& A. Portegies (Eds.), Voices in Tourism Development: Creating Spaces for Tacit Knowledge and Innovation Conference proceedings. Amsterdam: NHTV Expertise Series. 